\title{
RNA/DNA ratios of scleractinian corals suggest acclimatisation/adaptation in relation to light gradients and turbidity regimes
}

\author{
E. H. Meesters ${ }^{1}$, G. Nieuwland ${ }^{1}$, G. C. A. Duineveld ${ }^{1}$, A. Kok $^{1}$, R. P. M. Bak ${ }^{1,2, *}$ \\ ${ }^{1}$ Netherlands Institute for Sea Research (NIOZ), PO Box 59, 1970 AB Den Burg, Texel, The Netherlands \\ ${ }^{2}$ Institute for Biodiversity and Ecosystem Dynamics, University of Amsterdam, The Netherlands
}

\begin{abstract}
RNA/DNA ratios are used in many organisms as an indicator of growth, biomass or metabolic functioning. We hypothesised that hermatypic corals, as they depend for growth largely on energy transferred from their algal symbionts, may show an effect in the RNA/DNA ratio with factors influencing irradiance. This was tested along 2 environmental gradients: in relation to depth (decreasing irradiance) and in relation to environmental degradation (increased turbidity). RNA/DNA ratios were determined by HPLC in coral samples collected over depth gradients in 3 islands off the coast of north-west Java, Indonesia. The reefs range from shallow reefs $($ depth $<3 \mathrm{~m})$ in very turbid water, which are close to eroded shores, to intermediate reefs (depth $<6 \mathrm{~m}$ ) further from the shore with less turbid water, to offshore clear water control reefs (depth $<20 \mathrm{~m}$ ). RNA/DNA ratio was shown to be negatively correlated with depth in all but the most turbid conditions, suggesting it is an expression of metabolic acclimatisation of the coral host-symbiont community with decreasing irradiance (i.e. photoadaptation). Comparing the RNA/DNA ratio in clear and turbid waters, the decrease with depth tended to be steeper over a shorter depth range under turbid conditions, analogous with the more rapid extinction of light in these conditions. The relationship between the RNA/DNA ratio and light was consistently higher under turbid conditions ( $p=0.0037$ ), indicating that RNA/DNA ratio had shifted to a higher level, possibly indicating a genetic adaptation in the metabolic functioning of corals in the turbid environment. The positive relation between light and RNA/DNA ratio would suggest the opposite, i.e. lower ratio under turbid conditions. The RNA/DNA ratio may provide a relatively reliable method to determine the metabolic functioning (health) of individual coral colonies.
\end{abstract}

KEY WORDS: RNA/DNA ratios - Coral health · Environmental stress · Sediment · Turbidity · Photoadaptation $\cdot$ Growth $\cdot$ Bio-indicator

Resale or republication not permitted without written consent of the publisher

\section{INTRODUCTION}

Much work has been devoted in marine biology to applications of nucleic acid measurements, especially to the RNA/DNA ratio (Dell'anno et al. 1998, Stoeck et al. 1998, Buckley et al. 1999). The RNA/DNA ratio has been used as a biochemical growth-rate indicator, providing an estimate of growth rates and metabolic status in a wide variety of marine organisms such as larval fish

*Corresponding author. E-mail: rbak@nioz.nl
(Bulow 1987, Buckley et al. 1999, Kawakami et al. 1999, McNamara et al. 1999), phytoplankton (Dortch et al. 1983), copepods (Nakata et al. 1994, Wagner et al. 1998, Biegala et al. 1999), marine invertebrates (Wright \& Hetzel 1985, Frantzis et al. 1992, Pierce et al. 1999, Wo et al. 1999), and bacteria and microbial communities (Kerkhof \& Ward 1993, Dell'anno et al. 1998, Stoeck et al. 1998, Kerkhof \& Kemp 1999, Yu \& Mohn 1999). Some studies have found only poor or even no correlation between growth rate and the RNA/DNA ratio (e.g. Clarke et al. 1989, Anger \& Hirche 1990, Frantzis et al. 1992). 
The reasoning behind its use is that because RNA is an essential component of protein synthesis its concentration in tissues or samples often reflects the rate of protein synthesis. A relationship with organismal growth was established early on (Sutcliffe 1965, 1970). The RNA/DNA ratio provides an index of protein synthetic capacity per cell, since the amount of DNA per cell is assumed not to vary with condition or with growth rate. The RNA content of tissue is related to growth rate, food density, and temperature and may also be affected by gametogenesis and developmental stage.

Coral reefs worldwide are in decline as a result of increased use of the coastal zone and the related environmental pressures (Ginsburg \& Glynn 1994), possibly aggravated by indirect effects from global warming (Glynn 1991). Recent unprecedented degradation of reef areas as a consequence of bleaching (e.g. Hoegh-Guldberg 1999) has demonstrated the immediate need for better indicators of coral metabolic functioning or 'health'. How can we measure whether coral colonies are performing under less than optimal conditions? Parameters that have been suggested include stress proteins (Miller et al. 1992), tissue regeneration rate (Meesters \& Bak 1994), pulse amplitude modulated (PAM) fluorometry (Jones et al. 1999), coral lipids (Harriott 1993), ATP (Fang et al. 1987) mitotic indices (Brown \& Zamani 1992), coral calcification rates (Davies 1990), spectral analysis (Holden \& LeDrew 1998) and population structure (Bak \& Meesters 1999, Meesters et al. 2001). Here we want to present the RNA/DNA ratio as a measure of health in corals.

Although the RNA/DNA ratio is used as a growth/ health index in many organisms and communities, it has not been applied to scleractinian corals; although Gates \& Edmunds (1999) have given some preliminary results. We speculated that reduced light, through its effect on the energy metabolism of the endosymbiotic zooxanthellae (for reviews see Barnes \& Chalker 1990, Falkowski et al. 1990, Brown 1997), is likely to have a direct effect on the RNA/DNA ratio of the coral hostsymbiont association and we tested this in 2 ways. Firstly, the ratio was assessed in corals over a natural depth interval from 0.2 to $18 \mathrm{~m}$. Secondly, we compared ratios between colonies from 3 sites along a gradient in turbidity due to different sediment loading of the water column.

\section{MATERIALS AND METHODS}

Study area and sampling. We sampled reefs at 3 islands off the north-western coast of Java, Indonesia, from 10 to 17 April 1999 (Fig. 1). The 2 islands Gosong Dadapan and Pulau Kubur are situated in the turbid
Bay of Banten. Water clarity in Banten Bay is very low, probably due to strong resuspension of a former river delta in the eastern part of the bay causing a strong turbidity gradient (E. H. Meesters \& R. P. M. Bak unpubl. data). The third island, Pulau Tunda, is in the relatively clear water of the open Java Sea, approximately $17 \mathrm{~km}$ north of Banten Bay. Gosong Dadapan is the most inshore, close to a rapidly eroding muddy shore. Corals occur only over a very narrow depth range $(0.5$ to $3.1 \mathrm{~m})$. The island is now submerged, emerging partly at low tide. Pulau Kubur is farther away from the shore but still inside the muddy bay. Reefs here occur to a depth of $6 \mathrm{~m}$. At Pulau Tunda, corals grow in relatively clear water to depths of approximately $20 \mathrm{~m}$. The islands lie along an inshore to offshore turbidity gradient. This difference in turbidity between the islands was consistently observed during SCUBA dives. Light measurements were taken at high tide (variation tide level $<30 \mathrm{~cm}, \mathrm{~A}$. J. F. Hoitink \& P. Hoekstra unpubl.) during the period February 1998 until April 1999 using an IL 1400A light meter (International Light) equipped with a cosine corrected, underwater sensor (400 to $700 \mathrm{~nm}$ ). Mean extinction values at the sampling stations were $0.78(\mathrm{SD}=0.28, \mathrm{n}$ $=14$ profiles $)$ off Gosong Dadapan, $0.42(\mathrm{SD}=0.19, \mathrm{n}=$ 16) around Pulau Kubur and $0.26(\mathrm{SD}=0.031, \mathrm{n}=2)$ at Pulau Tunda. Due to the small sample size at Pulau Tunda, differences between Pulau Tunda and Pulau Kubur were not statistically significant, but data such as long-term sedimentation patterns $\left({ }^{210} \mathrm{~Pb}\right)$ from gravity cores, short-term sedimentation patterns from sediment traps and optical backscatter measurements (A. J. F. Hoitink \& G. D. van den Berg unpubl.) confirm the observed pattern in turbidity. Separate suspended sediment (SPM) readings during the whole period of study (January 1998 to April 1999) could be well above $100 \mathrm{mg} \mathrm{l}^{-1}$, but average concentrations were around $10 \mathrm{mg} \mathrm{l}^{-1}$ in the bay and $1.4 \mathrm{mg} \mathrm{l}^{-1}$ in the Java Sea.

Colonies of massive Porites species were sampled at the north-western sides of Pulau Kubur and Gosong Dadapan and at the northern side of Pulau Tunda. Due to extremely large variation in skeletal micro-characteristics of colonies, we were not able to determine species names. In terms of traditional taxonomy, sampled colonies were either Porites lutea or P. lobata. Large and overlapping variation in skeletal characteristics both within and between colonies and between colonies in different environments has now been acknowledged, preventing confident identification in the genus Porites (Veron 1995). For the purpose of our study, it is relevant to realise that variation in DNA and RNA is likely to be minimal or non-detectable between congenerics G.C.A.D. pers. obs.). From each colony, we took a small (1 cm diameter) core from the top of the colony with a pneumatic drill. Each core was cut 


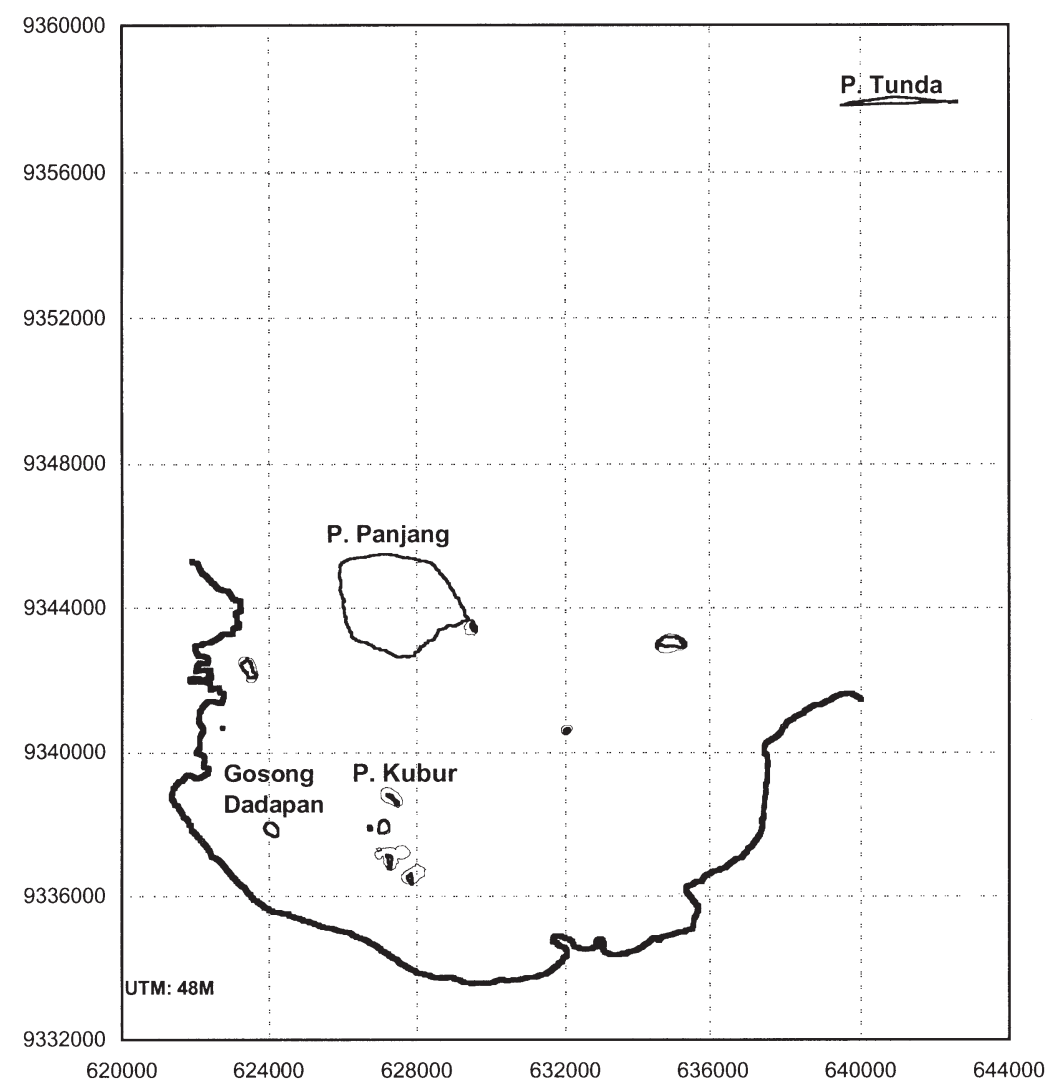

Fig. 1. Geographic map of Banten Bay, north-west Java, Indonesia. Sampling sites are Gosong Dadapan and Pulau Kubur inside Banten Bay, and Pulau Tunda outside the bay in the Java Sea. The thin lines around islands represent reef contour (ca. $3 \mathrm{~m}$ isobath). UTM: Universal Transvers Mercator. Scale is in $\mathrm{m}$

below the coral tissue and stored in liquid nitrogen within 10 min of reaching the surface.

RNA and DNA determination. Samples were kept below $-80^{\circ} \mathrm{C}$ and not allowed to thaw at any time. Samples were analysed with high performance liquid chromatography (HPLC) using a procedure first described by Coppela et al. (1987) and modified by A.K. (Stoeck et al. 1998). The lower detection border lies at 10 ng DNA, or RNA. Calibration curves were highly significant $\left(r^{2}\right.$ of all $\left.>0.99\right)$. Recovery for both RNA and DNA was on average $97 \%$. A sub-sample of each core was freeze-dried and digitally photographed for surface area calculation by image analysis. To minimise a possible effect of endolithic organisms, we removed as much skeleton as possible from under the coral tissue layer. However, Porites coral tissue is located partially inside the porous skeleton and not all skeleton was removed. Coral cores were ground including the remaining skeleton. The resulting powder was added to $1 \mathrm{ml}$ of Tris- $\mathrm{HCl}$ buffer and sonicated 10 times $(10 \mathrm{~s}$ with 1 min intervals). After sonication, samples were centrifuged for $5 \mathrm{~min}(3000 \times g)$ and the supernatant was filtered over a $0.45 \mu \mathrm{m}$ pore size cellulose acetate filter to remove particulate material. The filtrate was directly injected into the HPLC system, which consisted of a Waters 616 pump and Waters 600S controller unit, connected via a Nucleogen 4000-7 DEAE anion-exchange column (Macherey-Nagel, Düren) to a Waters 486 tunable absorbance detector. Peak identity in the chromatogram was confirmed by inspection of the absorbance spectrum (DNA and RNA maximum absorbance at $260 \mathrm{~nm}$ ) in combination with either co-injection of standards (calf thymus DNA and baker's yeast RNA) or digestion of RNA with RNase. The areas of the peaks were integrated at $260 \mathrm{~nm}$ wavelength. Gradient flow rate and composition of eluents used for HPLC determination were as in Dell'anno et al. (1998).

\section{RESULTS}

A typical HPLC plot is given in Fig. 2. The 3 peaks from left to right were identified as tRNA, rRNA and DNA. Table 1 gives the RNA/DNA concentrations, the ratios, depths and location of each sample. The ratios vary between 0.60 and 1.04. At Pulau Tunda and Pulau Kubur, there is a significant relationship between the ratio and sample depth (Table 2). A large degree of the variation in the ratio of the different samples can be explained by depth (respectively 81 and $96 \%$ ). The RNA/DNA samples from Gosong Dadapan come from a very narrow depth range (only $2.5 \mathrm{~m}$ ) and there is no variation between samples $(p=0.314)$. The regression

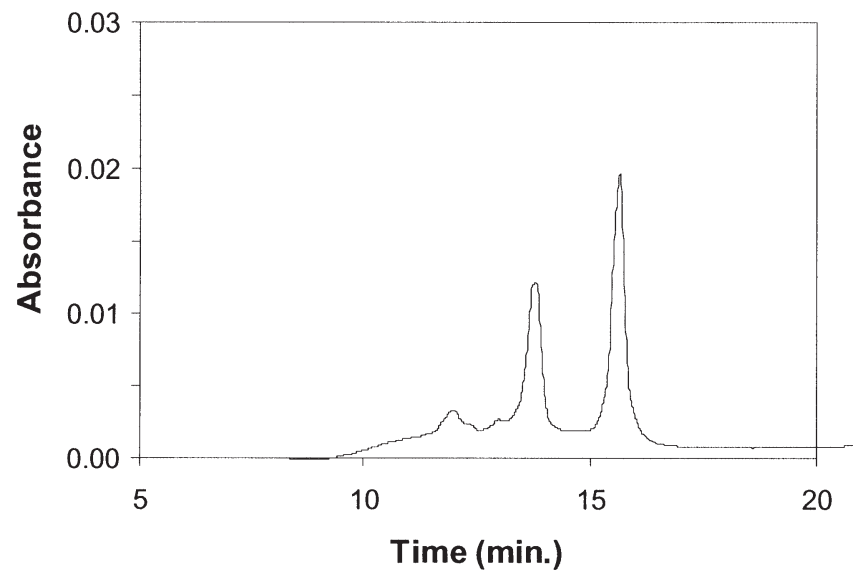

Fig. 2. Typical HPLC plot of coral sample. The 3 peaks were identified as tRNA, rRNA and DNA (from left to right) 
slopes of Pulau Kubur and Pulau Tunda are significantly different from zero (Table 2). The RNA/DNA ratio appears to decrease faster with depth at Pulau Kubur, but the slopes were not significantly different (ANOVA test for differences between slopes, $F_{1,17}=$ 1.99, $\mathrm{p}=0.18$ ). However, when correcting for the differences in depth by analysis of covariance (ANCOVA), the ratios between Pulau Kubur and Pulau

Table 1. RNA/DNA concentrations and ratios of coral cores from the 3 islands. Depth is the depth at the surface of the sampled coral colony. Percentage irradiance based on average extinction coefficient (see 'Materials and methods')

\begin{tabular}{|c|c|c|c|c|c|}
\hline Island & $\begin{array}{l}\text { Depth } \\
\text { (m) }\end{array}$ & $\begin{array}{c}\text { RNA } \\
\left(\mu \mathrm{g} \mathrm{cm}^{-2}\right)\end{array}$ & $\begin{array}{c}\text { DNA } \\
\left(\mu \mathrm{g} \mathrm{cm}^{-2}\right)\end{array}$ & Ratio & $\begin{array}{c}\% \\
\text { irradiance }\end{array}$ \\
\hline \multicolumn{6}{|c|}{ Gosong Dadapan } \\
\hline & 0.5 & 239 & 293 & 0.82 & 67.7 \\
\hline & 0.6 & 364 & 443 & 0.82 & 62.6 \\
\hline & 1.3 & 217 & 291 & 0.74 & 36.3 \\
\hline & 2.3 & 156 & 191 & 0.81 & 16.6 \\
\hline & 2.3 & 165 & 210 & 0.78 & 16.6 \\
\hline & 2.3 & 133 & 166 & 0.80 & 16.6 \\
\hline & 3.1 & 112 & 147 & 0.76 & 8.9 \\
\hline \multicolumn{6}{|c|}{ Pulau Kubur } \\
\hline & 1.2 & 286 & 309 & 0.93 & 60.4 \\
\hline & 1.5 & 328 & 356 & 0.92 & 53.3 \\
\hline & 2.2 & 98 & 113 & 0.87 & 39.7 \\
\hline & 5.1 & 171 & 220 & 0.78 & 11.7 \\
\hline & 5.6 & 91 & 127 & 0.72 & 9.5 \\
\hline \multicolumn{6}{|c|}{ Pulau Tunda } \\
\hline & 0.2 & 298 & 286 & 1.04 & 94.9 \\
\hline & 0.3 & 376 & 415 & 0.91 & 92.5 \\
\hline & 1 & 365 & 428 & 0.85 & 77.1 \\
\hline & 1 & 361 & 442 & 0.82 & 77.1 \\
\hline & 1.1 & 223 & 253 & 0.88 & 75.1 \\
\hline & 1.3 & 150 & 172 & 0.87 & 71.3 \\
\hline & 2.3 & 210 & 303 & 0.69 & 55.0 \\
\hline & 2.8 & 272 & 372 & 0.73 & 48.3 \\
\hline & 5.5 & 222 & 339 & 0.65 & 23.9 \\
\hline & 7 & 188 & 294 & 0.64 & 16.2 \\
\hline & 7.1 & 196 & 251 & 0.78 & 15.8 \\
\hline & 10.1 & 116 & 173 & 0.67 & 7.2 \\
\hline & 11.5 & 143 & 201 & 0.71 & 5.0 \\
\hline & 12.6 & 113 & 159 & 0.71 & 3.8 \\
\hline & 17.1 & 89 & 134 & 0.66 & 1.2 \\
\hline & 19.7 & 100 & 166 & 0.60 & 0.6 \\
\hline
\end{tabular}

Table 2. Regression of RNA/DNA ratio vs depth. Data fitted to the line: RNA/DNA $=C+[k \times \log ($ Depth $)]$, in which $C$ is a constant, $k$ is the regression slope and $\log$ is the logarithm base 10

\begin{tabular}{|lcccr|}
\hline Island & $C$ & $k$ & $r^{2}$ & \multicolumn{1}{c|}{$p$} \\
\hline Gosong Dadapan & 0.80 & -0.041 & 0.20 & 0.314 \\
Pulau Kubur & 0.96 & -0.295 & 0.96 & 0.003 \\
Pulau Tunda & 0.85 & -0.174 & 0.81 & $<0.001$ \\
\hline
\end{tabular}

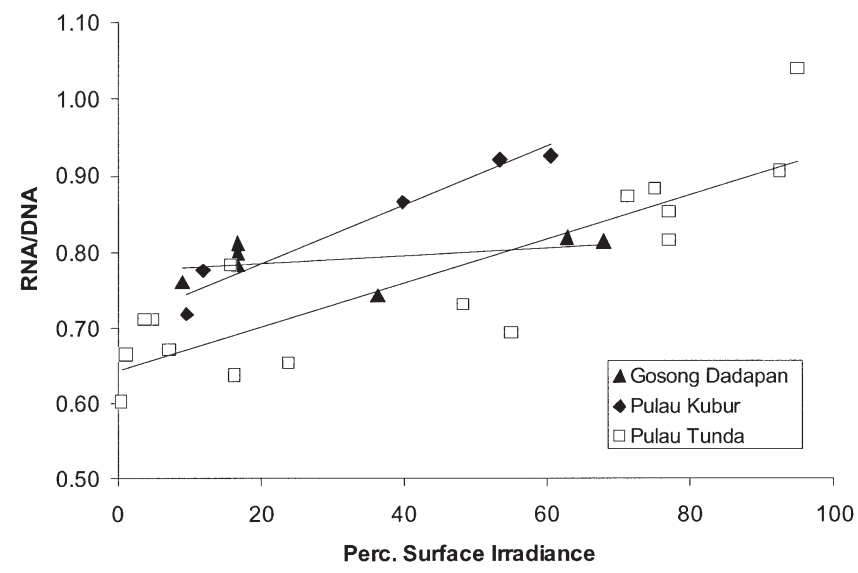

Fig. 3. RNA/DNA ratio vs estimated percentage light at the measured depth. Percentage light was estimated by using average extinction values for each site (see 'Materials and methods')

Tunda are significantly different $\left(F_{1,18}=5.70, \mathrm{p}=0.028\right.$; adjusted least-squares means, respectively 0.83 and 0.77 ; SE 0.02 and 0.01).

Fig. 3 shows that the range in surface irradiance of the samples from the 3 islands is very similar. If light is exclusively responsible for the variation between the different islands, the data points should lie on the same line. However, corals from Pulau Kubur appear to have higher RNA/DNA ratios than corals at Pulau Tunda. Because irradiance is derived from depth, regression results are similar to those for depth (Table 2). Corals from Gosong Dadapan do not show a significant relationship with light, while the 2 other islands do. The slopes from Pulau Tunda and Pulau Kubur are not significantly different (ANOVA test for differences between slopes, $F_{1,17}=0.50, \mathrm{p}=0.49$ ), but the RNA/DNA ratio in corals from Pulau Kubur is significantly higher (ANCOVA, $F_{1,18}=11.1, \mathrm{p}=0.0037$; adjusted least-squares means, respectively 0.86 and 0.76 ; SE 0.026 and 0.014).

\section{DISCUSSION}

\section{RNA/DNA ratios and depth}

We found a clear negative relationship between the RNA/DNA ratio and depth in 2 of the 3 locations. Because irradiance decreases exponentially with depth (Jerlov 1968), the exponential decrease of RNA and DNA with depth found in this study supports the hypothesis that light is the primary responsible factor. Metabolism and growth in scleractinian hermatypic corals depend mainly on irradiance, and many studies have shown the effect of light or depth on these processes 
(e.g. Yonge \& Nicholls 1931, Bak 1974, Falkowski \& Dubinsky 1981, Titlyanov 1981, Chalker et al. 1983, Dubinsky et al. 1984, Falkowski et al. 1984, Muscatine et al. 1984, Bosscher \& Meesters 1992). The adaptation of corals to light has been termed photoadaptation, and it involves a whole spectrum of responses ranging from changes at the cellular level to behavioural and growth form variations (Brown 1997). The decrease in RNA/ DNA ratio reflects metabolic effects that are related to the dependence of the coral host-symbiont community on light and should be viewed as a phenotypic (photo) adaptation. The reduction in RNA/DNA ratio suggests that protein synthesis per cell decreases with light intensity. A similar decrease has been found for the $P / R$ ratio, another measure of performance in relation to depth (McCloskey \& Muscatine 1984).

\section{Turbidity}

The spectral quality/quantity of submarine light field is influenced by dissolved and suspended substances. This means that the extremely turbid conditions in the bay create a very different spectral environment for the corals compared to the environment outside of the bay. Regarding the 3 study sites, we see that samples from Gosong Dadapan did not show a decline in the RNA/DNA ratio with depth. Gosong Dadapan lies very close to the shore (Fig. 1), and consequently environmental variations in sedimentation, turbidity, salinity, and temperature are larger than at Pulau Kubur and much larger than at Pulau Tunda. There is a strong gradient in turbidity, ranging from very high near the coast to low further away into the Java Sea. Average extinction values $\left(k^{\prime}\right)$ for Gosong Dadapan, Pulau Kubur, and Pulau Tunda were respectively 0.78, 0.42, and 0.26 (see 'Materials and methods'). For Gosong Dadapan and Pulau Kubur, these correspond to a sediment load of approximately 4.6 and $1.9 \mathrm{mg} \mathrm{l}^{-1}$ (using an empirically established relation for Teluk Banten between suspended particular matter (SPM) in $1^{-1}$ and average extinction, $k^{\prime}: k^{\prime}=-0.1034 \mathrm{SPM}-0.1607 ; \mathrm{r}^{2}=$ 0.89. However, incidental turbidity readings were found to be in excess of $10 \mathrm{mg}^{-1}$. Sedimentation values at Gosong Dadapan were often twice as high as at Pulau Kubur and ranged from 50 to $150 \mathrm{~g} \mathrm{~m}^{-2} \mathrm{~d}^{-1}$. These extreme environmental conditions at Gosong Dadapan appear to distort the relation between the RNA/DNA ratio and depth found at the 2 other islands.

\section{Adaptation or acclimatisation}

The corals of Pulau Kubur live under relatively turbid conditions when compared to corals at Pulau
Tunda. They show a similar response with light (i.e. a comparable decrease in the ratio with increasing depth), but, remarkably, the RNA/DNA ratio is consistently higher (Fig. 3). This indicates that corals at Pulau Kubur are metabolically more active than at Pulau Tunda. This is either phenotypic acclimatisation or genetical adaptation.

The relationship between the RNA/DNA ratio and light is the same at the 2 islands, but raised to a higher level at Pulau Kubur. This may indicate that corals at Pulau Kubur have become genetically adapted. However, similar phenomena (resulting from genetical adaptation or phenotypic acclimatisation) have been observed in metabolic responses of poikilotherms to temperature (e.g. Berggren \& Roberts 1991). Corals at Pulau Kubur may profit in some way from the turbid waters in the bay, e.g. by digesting sediment particles (Anthony 1999). The fact that the RNA/DNA ratio runs parallel at a higher value over the whole range of the environmental variable (light) suggests that the adaptation is genetic. If sediment ingestion were responsible, the reaction of the corals would not be similar over all depths, because sediment concentrations in the bay show a constant gradient with higher concentrations at greater depths (E.H.M. unpubl.). Possibly, corals at Pulau Kubur have obtained a different strain of zooxanthellae that are more efficient at the ambient irradiance levels (Chang et al. 1983, Rowan et al. 1997), but more detailed studies are needed to resolve this enigma of better performing corals under increased sediment stress.

No previous study has reported the use of RNA/DNA ratios in corals in studying the condition of the colony. The only reference to RNA/DNA ratios in corals comes from preliminary data mentioned in Gates \& Edmunds (1999). They state that ratios in 10 clonal genotypes of the coral Madracis mirabilis vary by a factor of 5; however, no data are shown. This would suggest that there may be large interspecific differences between species, because in our study ratio differences in a dataset containing 2 species (Porites lobata and P. lutea) are less than a factor of 2. Our study indicates that the use of RNA/DNA ratios as a measure of metabolic functioning could be an indicator for 'health' in scleractinian corals. Protein turnover should be intrinsically linked to growth, metabolism and acclimatisation potential conditions (Gates \& Edmunds 1999). Because RNA synthesis is fundamental to protein metabolism, the study of RNA and DNA concentrations may provide additional insights in the responses of coral organisms to environmental stress.

Further research should include temporal (seasonal) variation in RNA/DNA concentrations, as well as interspecific and intra-colony variation. Our preliminary tests have indicated that the variation in the ratios 
between colonies from the same depth are very similar (average difference $8 \%, \mathrm{n}=7$ pair of colonies); ratios from different samples from the top of the same colony varied $4 \%$ ( $\mathrm{n}=5$ pairs of colonies).

In conclusion, we developed an accurate and sensitive assay to measure RNA and DNA concentrations in coral samples. RNA/DNA ratios were shown to be sensitive to differences in depth, most likely reflecting differences in light regime and as such indicative of photoadaptation. The measurement of RNA and DNA concentrations may provide a sensitive measure of coral colony response to environmental change.

Acknowledgements. We would like to thank the people of the Bojonegara research station, specifically Mr Muhajir for his assistance with the fieldwork. We are grateful to Wawan Kiswara and Dr Suharsono of the Indonesian Institute of Sciences (LIPI). We would also like to thank anonymous reviewers whose comments benefited the manuscript. This project was part of the Teluk Banten programme, a LOICZ research project of the International Geosphere-Biosphere Programme: A study of Global Change (IGBP) of the International Council of Scientific Unions (ICSU), and funded by The Netherlands Foundation for the Advancement of Tropical Research (WOTRO), project W84-418. This is NIOZ publication number 3672.

\section{LITERATURE CITED}

Anger K, Hirche HJ (1990) Nucleic acids and growth of larval and early juveniile spider crab, Hyas araneus. Mar Biol 105:403-411

Anthony KRN (1999) Coral suspension feeding on fine particulate matter. J Exp Mar Biol Ecol 232:85-106

Bak RPM (1974) Available light and other factors influencing growth of stony corals through the year in Curacao. Proc 2nd Int Coral Reef Symp, Brisbane, 2:229-233

Bak RPM, Meesters EH (1999) Population structure as a response of coral communities to global change. Am Zool 39:56-65

Barnes DJ, Chalker BE (1990) Calcification and photosynthesis in reef-building corals and algae. In: Dubinsky Z (ed) Ecosystems of the world. Elsevier Science Publishers, Amsterdam, p 109-131

Barnes DJ, Lough JM (1999) Porites growth characteristics in a changed environment: Misima Island, Papua New Guinea. Coral Reefs 18:213-218

Berggren W, Roberts JL (1991) Respiration and metabolism. In: Ladd Prosser C (ed) Environmental and metabolic animal physiology. Wiley-Liss Inc, New York, p 353-436

Biegala IC, Harris RP, Bergeron JP (1999) ATCase activity, RNA:DNA ratio, gonad development stage, and egg production in the female copepod Calanus helgolandicus. Mar Biol 135:1-10

Bosscher H, Meesters EH (1992) Depth related changes in the growth of Montastrea annularis. Proc 7th Int Coral Reef Symp, Guam 1:507-512

Brown BE (1997) Adaptations of reef corals to physical environmental stress. Adv Mar Biol 31:221-299

Brown BE, Zamani NP (1992) Mitotic indices of zooxanthellae: a comparison of techniques based on nuclear and cell division frequencies. Mar Ecol Prog Ser 89:99-102
Buckley L, Caldarone E, Ong TL (1999) RNA-DNA ratio and other nucleic acid-based indicators for growth and condition of marine fishes. Hydrobiologia 401:265-277

Bulow FJ (1987) RNA-DNA ratios as indicators of growth in fish: a review. In: Summerfelt RC, Hall GC (eds) The age and growth of fish. Iowa State University Press, Ames, p 45-65

Chalker BE, Dunlap WC, Oliver JK (1983) Bathymetric adaptations of reef-building corals at Davies reef, Great Barrier Reef, Australia. II Light saturation curves for photosynthesis and respiration. J Exp Mar Biol Ecol 73:37-56

Chang SS, Prezelin BB, Trench RK (1983) Mechanisms of photoadaptation in three strains of the symbiotic dinoflagellate Symbiodinium microadriaticum. Mar Biol 76:219-229

Clarke A, Rodhouse PG, Holmes LJ, Pascoe PL (1989) Growth rate and nucleic acid ratio in cultured cuttlefish Sepia officinalis (Mollusca: Cephalopoda). J Exp Mar Biol Ecol 133:229-240

Coppella SJ, Acheson CM, Dhurjati P (1987) Isolation of highmolecular-weight nucleic acids for copy number analysis using high-performance liquid chromatography. J Chromatogr 402:189-199

Davies PS (1990) A rapid method for assessing growth rates of corals in relation to water pollution. Mar Pollut Bull 21: 346-348

Dell'anno A, Fabiano M, Duineveld GCA, Kok A, Danovaro R (1998) Nucleic acid (DNA, RNA) quantification and RNA/DNA ratio determination in marine sediments: Comparison of spectrophotometric, fluorometric, and HighPerformance Liquid Chromatography methods and estimation of detrital DNA. Appl Environ Microbiol 64: 3238-3245

Dortch QF, Roberts TL, Clayton JR, Ahmed SI (1983) RNA:DNA ratios and DNA concentrations as indicators of growth rate and biomass in planktonic organisms. Mar Ecol Prog Ser 13:61-71

Dubinsky Z, Falkowski P, Porter J, Muscatine L (1984) Absorption and utilization of radiant energy by light- and shade-adapted colonies of the hermatypic coral Stylophora pistillata. Proc R Soc Lond B 222:203-214

Falkowski PG, Dubinsky Z (1981) Light-shade adaptation of Stylophora pistillata, a hermatypic coral from the Gulf of Eilat. Nature 289:172-174

Falkowski PG, Dubinsky Z, Muscatine L, Porter JW (1984) Light and the bioenergetics of a symbiotic coral. Bioscience 34:705-709

Falkowski PG, Jokiel PL, Kinzie RA (1990) Irradiance and corals. In: Dubinsky Z (ed) Ecosystems of the world. Elsevier Science Publishers, Amsterdam, p 89-107

Fang LS, Chen YWJ, Soong KY (1987) Methodology and measurement of ATP in coral. Bull Mar Sci 41:605-610

Frantzis A, Gremare A, Vetion G (1992) Growth rates and RNA/DNA ratios in Paracentrotus lividus (Echinodermata: Echinoidea) fed on benthic marcrophytes. J Exp Mar Biol Ecol 156:125-138

Gates RD, Edmunds PJ (1999) The physiological mechanisms of acclimatization in tropical reef corals. Am Zool 39:30-43

Ginsburg RN, Glynn PW (1994) Summary of the colloquium and forum on global aspects of coral reefs: health, hazards and history. In: Ginsburg RN (ed) Proc Colloquium Global Aspects of Coral Reefs. RSMAS, University of Miami, Miami, p i-ix

Glynn PW (1991) Coral reef bleaching in the 1980s and possible connections with global warming. Trends Ecol Evol 6: 175-179

Harriott, VJ (1993) Coral lipids and environmental stress. Environ Monit Assess 25:131-139 
Hoegh-Guldberg O (1999) Climate change, coral bleaching and the future of the world's coral reefs. Mar Freshw Res 50:839-866

Holden H, LeDrew E (1998) Spectral discrimination of healthy and non-healthy corals based on cluster analysis, principal components analysis, and derivative spectroscopy. Remote Sens Environ 65:217-224

Jerlov NG (1968) Optical oceanography. Elsevier Science Publishers, Amsterdam

Jones RJ, Kildea T, Hoegh-Guldberg O (1999) PAM chlorophyll fluorometry: a new in situ technique for stress assessment in scleractinian corals, used to examine the effects of cyanide from cyanide fishing. Mar Pollut Bull 38: 864-874

Kawakami Y, Mochioka N, Kimura R, Nakazono A (1999) Seasonal changes of the RNA/DNA ratio, size and lipid contents and immigration adaptability of Japanese glasseels, Anguilla japonica, collected in northern Kyushu, Japan. J Exp Mar Biol Ecol 238:1-19

Kerkhof L, Kemp P (1999) Small ribosomal RNA content in marine Proteobacteria during non-steady-state growth. FEMS Microbiol Ecol 30:253-260

Kerkhof L, Ward BB (1993) Comparison of nucleic acid hybridization and fluorometry for measurement of the relationship between RNA/DNA ratio and growth rate in a marine bacterium. Appl Environ Microbiol 59:1303-1309

McCloskey LR, Muscatine L (1984) Production and respiration in the Red Sea coral Stylophora pistillata as a function of depth. Proc R Soc Lond B 222:215-230

McNamara PT, Caldarone EM, Buckley LJ (1999) RNA/DNA ratio and expression of $18 \mathrm{~S}$ ribosomal RNA, actin and myosin heavy chain messenger RNAs in starved and fed larval Atlantic cod (Gadus morhua). Mar Biol 135:123-132

Meesters EH, Bak RPM (1994) Regeneration of tissue lesions in corals: a biomonitoring tool? In: Bellwood O (ed) Abstracts 6th Pacific Congress on Marine Science and Technology (PACON), Townsville, p 199

Meesters EH, Hilterman M, Kardinaal E, Keetman M, de Vries M, Bak RPM (2001) Colony size-frequency distributions of scleractinian coral populations: spatial and interspecific variation. Mar Ecol Prog Ser 209:43-54

Miller D, Brown BE, Sharp VA, Nganro N (1992) Changes in the expression of soluble proteins extracted from the symbiotic anemony Anemonia viridis acompany bleaching induced by hyperthermia and metal stressors. J Therm Biol 17:217-223

Muscatine L, Falkowski PG, Porter JW, Dubinsky Z (1984) Fate of photosynthetic fixed carbon in light- and shade-

Editorial responsibility: Otto Kinne (Editor),

Oldendorf/Luhe, Germany adapted colonies of the symbiotic coral Stylophora pistillata. Proc R Soc Lond B 222:181-202

Nakata K, Nakano H, Kikuchi H (1994) Relationship between egg productivity and RNA/DNA ratio in Paracalanus sp. in the frontal waters of the Kurshio. Mar Biol 119:591-596

Pierce GJ, Key LN, Boyle PR, Siegert KJ, Goncalves JM, Porteiro FM, Martins HR (1999) RNA concentration and the RNA to protein ratio in cephalopod tissues: sources of variation and relationship with growth rate. J Exp Mar Biol Ecol 237:185-201

Rowan R, Knowlton N, Baker A, Jara J (1997) Landscape ecology of algal symbionts creates variation in episodes of coral bleaching. Nature 388:265-269

Stoeck T, Duineveld G, Kok A, Albers BP (1998) Extraktion und Quantifizierung von Nukleinsäuren aus Sedimenten. In: Remde A, Tippmann P (eds) Mikrobiologische Characterisierung aquatischer Sedimente-Methodensammlung. R. Oldenbourg Verlag, Munich, p 47-58

Sutcliffe WHJ (1965) Growth estimates from ribonucleic acid content in some small animals. Limnol Oceanogr 10(Suppl): R253-R258

Sutcliffe WHJ (1970) Relationship between growth rate and ribonucleic acid concentration in some invertebrates. J Fish Res Board Can 27:606-609

Titlyanov EA (1981) Adaptation of reef-building corals to low light intensity. Proc 4th Int Coral Reef Symp 2 Manila 2:39-43

Veron JEN (1995) Corals in space and time. Cornell University Press, Ithaca, NY

Wagner M, Durbin E, Buckley L (1998) RNA:DNA ratios as indicators of nutritional condition in the copepod Calanus finmarchicus. Mar Ecol Prog Ser 162:173-181

Wo KT, Lam PKS, Wu RSS (1999) A comparison of growth biomarkers for assessing sublethal effects of cadmium on a marine gastropod, Nassarius festivus. Mar Pollut Bull 39: 165-173

Wright DA, Hetzel EW (1985) Use of RNA:DNA ratios as an indicator of nutritional stress in the American oyster Crassostrea verginica. Mar Ecol Prog Ser 25:199-206

Yonge CM, Nicholls AG (1931) Studies on the physiology of corals. V. The effect of starvation in light and in darkness on the relationship between corals and zooxanthellae. Great Barrier Reef Expedition 1928-29. Scientific reports. British Museum (Natural History), Vol 1, London, p 177-211

Yu ZT, Mohn WW (1999) Killing two birds with one stone: simultaneous extraction of DNA and RNA from activated sludge biomass. Can J Microbiol 45:269-272

Submitted: March 30, 2000; Accepted: August 9, 2001

Proofs received from author(s): January 28, 2002 